\title{
Personal Narrative on the Education Processes in Bosnia-Herzegovina
}

J. Cynthia McDermott *

Lejla Panjeta** $^{* *}$

\begin{abstract}
The first section of this paper describes briefly the history of education reform in the former Yugoslavia. Under the leadership of Josip Broz Tito (1892-1980), who made a significant and lasting commitment to education, vast improvements were made in the educational system. The significant legislative reforms in the education system were introduced under Tito's regime. Then, this paper also weaves together the personal narrative of Professor Lejla Panjeta, a student during the 1472 day siege of Sarajevo. Students' commitment to receive the education regardless of the physical dangers clearly reflects the role of education in a modern context. The paper concludes with a brief analysis of the post-conflict educational process in Bosnia-Herzegovina.
\end{abstract}

Keywords: Bosnian War, University of Sarajevo, Education, Josip Broz Tito, 1472, Siege of Sarajevo, Conflict and Former Yugoslavia

\footnotetext{
*Corresponding author: J. Cynthia McDermott, Ed.D. Antioch University Los Angeles (AULA), 400 Corporate Pointe Culver City, CA 90230, USA, E-mail: cmcdermott@ antioch.edu

** Corresponding author: Lejla Panjeta, Ph.D., Associate Professor, International University of Sarajevo (IUS), Faculty of Arts and Social Sciences (FASS), Sarajevo, Bosnia and Herzegovina, E-mail: 1panjeta@ius.edu.ba
} 
Bosnia-Herzegovina's picturesque and ancient city of Sarajevo, host to the 1984 Winter Olympics, was torn asunder from April 6, 1992 until February 29, 1996 when it was caught in a war that eventually contributed towards breakup of Yugoslavia. The city suffered in a siege that lasted for more than four years. During that time, however, many attempts were made to continue with the education process, which in effect demonstrated the deeply rooted belief of the former Yugoslavia citizens about the importance of education. Receiving an education was so significant that it overpowered the fear and daily brutality of war, giving Sarajevo's citizens the courage to walk to class in the random death and destruction of artillery shells and sniper fire raining down on the population. What drives someone to keep their wits and spirit under such circumstances?

Lejla Panjeta, a student during the time of the Sarajevo siege and now a professor, sits in a chair, her back to a window overlooking the city sipping a cup of Bosnian coffee. She talks about the importance of education for herself and many fellow students during this time of violence and strife:

From home to school you might run into a speck of blood on the sidewalk, a piece of brain in the grass or a part of a liver on a twig. We would avoid the intersection where there was shooting and wait for the right moment to avoid getting shot at and if we avoided a sniper's bullet, we won a small victory. We would arrive at school and sit quietly while shells burst outside, with the walls shaking, with the glassless windows covered with waving UNPROFOR's nylon foil (United Nations Protecting Forces), which we wanted to believe had the power to protect us from death itself.

The territory of the former Yugoslavia (the Socialist Federal Republic of Yugoslavia - SFRJ) has a 3000-year history. For centuries, the Balkans has been an important geopolitical region, described historically as the crossroads between the East and West. Throughout time, the Balkans were a prized territory, desired and occupied by Romans, Ottomans, Austro-Hungarians, and during the World War II by Nazis. Yugoslavia came into existence as a result of World War I and was ruled by Kings. With the fall of the Austria-Hungary Empire at the end of WWI, the victors created a new country comprising of many 
different ethnic groups including peoples from Serbia, Montenegro, Kosovo, Slovenia, Macedonia, Croatia and Bosnia.

The first education institution in Bosnia and Herzegovina was established by Gazi Husrev Bey in 1531 as the high school of Sufi philosophy where three classical academic fields at the time were taught: theology, law, philosophy (Čaklovica 2010). The first university library was founded here also.

In 1937 Josip Broz Tito, who had established himself as an organizer and supporter of the common person, had become the head of the Yugoslav Communist Party. Through his efforts and with the determination of thousands of partisan citizens, Yugoslavia was liberated from Nazi occupation in 1945. From 1945 to 1963, Tito acted as Prime Minister and President of the Federal Executive Council and the first President of Yugoslavia. In 1963, Tito was named President for Life. Unlike most Socialist leaders at the time, Tito was well respected by many inside and outside his country. Tito died in 1980, thrusting his unified Yugoslavia into civil war, chaos and political instability, eventually leading to the war that engulfed Sarajevo and many parts of the former Yugoslavia.

Tito's life was deeply devoted to the worker and unions as an outspoken supporter of Communism. As a result, Tito held a firm belief in the concept of self-determination. He created within Yugoslavia a form of Socialism that was eventually identified as "Titoism."

Of particular interest for this paper are the education policies and practices during Tito's reign. His aims for education matched his socialistic perspective. According to Krste Crvenkovski (1961), a minister of education and culture in former Yugoslavia, Tito believed in the power of education and wanted all citizens to have an opportunity to advance within the limits of their mental capacities throughout their lifetime. The people of Yugoslavia enthusiastically embraced Tito's vision. Evidence of how important education became for the citizens of Yugoslavia can be understood by viewing their risk-taking under unbearable economic and social conditions that the war created. According to Professor Lejla's recollection: 
Our school life during the siege was bizarre. There were no grades, evaluations, debating or PowerPoint presentations. There were no such things as Websites or URL references. Although at the time these were just beginning to sneak into the academic work worldwide. We used worn out pens and old agendas. We borrowed typewriters and used improvised wick lanterns to write term papers or articles since there was no electricity. We didn't have to worry about violating copyright laws by Xeroxing books for one simple reason: there were no books for the students or teachers. They were blown to bits in shelling or burned for fuel to keep people alive. Sometimes a stray book saved from the faculty or a university library, or someone's private collection surfaced. We knew the value of what we had, since that book could have been used to warm a room or heat a lunch.

The students attending the university during this war were not just a dedicated few. There were many who understood that the future to finding a solution to the complex issues facing Sarajevo and the region was education. The importance of an open and free educational system was considered a basic birth right for those struggling to educate themselves in Sarajevo. In that sense, Tito's ideas about the importance of access to higher education had succeeded on a grand scale.

The writing and development of the Constitution was key to the creation of a national school system. Basic principles were constructed and affirmed: the standard of complete democracy in schooling and the equality of nations and their right to be educated, the principle of school secularization and the principle of the education of youngsters in accordance with the accomplishments of the spirit of the fight for national liberation. After wide discussion and deliberation, all schools and teaching institutions embraced the spirit of these principles. In 1954, committees across Yugoslavia adopted the General Law on Education. According to Petar Živojnović (1959) during the Session of the Federal People's Assembly in June 1958 the following aims for education were incorporated: to (a) enable the young generation to contribute with their work based on modern scientific and technical results towards the constant development of social and productive forces; (b) strengthen the socialistic social bases in order to increase the common material and cultural situation; (c) improve individual progress of any working man; (d) develop awareness of social 
responsibility in young people's minds and to provoke their active participation in social life and social self-management; and (e) improve physical education of youths in order to increase working abilities and healthy life of an individual (Article 3) (pp. 469-477).

Tito's expectations for the country were clear: advance the population through education. Concepts such as life-long learning and adult education were incorporated into each education level and access became available to all.

Article 38 of the Constitution of the FNRJ (the Federal People's Republic of Yugoslavia) from 31 February 1946 points out:

In order to achieve a higher level of the general culture of the people, schools and other teaching institutions are available to all the classes of people. The State owns the schools; they could be private if they are allowed to be, but under the state's control. Basic education is compulsory and free of charge. Schools are separated from the church.

Professor reaches for a cookie from a plate on the table, looks out the window and continues:

The complete works of Kardelj and Tito cooked the most of our food. Communism had collapsed, but in a most ironic sense it was still feeding its people. During the Siege of the University of Sarajevo, material manifestations of knowledge were all destroyed, including every building and all books. Classes took place anywhere. There were professors who were afraid to come out into the street so they held classes in their homes. There were some who never left their shelters for a year. On the other hand, the majority of "twisted" professors came to their lectures and pretended that nothing unusual was happening.

Zivojnović (1959) comments further to elaborate on Tito's vision and states, "the internal life and work of the schools should contribute to the development of initiative, independent activity and the cultural level of the work of the pupil; to getting accustomed to independent, thorough study, development of interest in things, independent judgment and critical spirit to development of social life among pupils and mutual respect and confidence between pupils and teachers" (p. 474). 
Crvenkovski (1961) asserted that further efforts of reform occurred with the passage of the Law of July 1960 with the intention of creating a system that was coherent and, more importantly, would further democratize the school system. A significant desire on the part of the educational reformers was to have traditional ethnic, religious and the more virulent national identities automatically disappear as greater industrialization, literacy and urbanization ware achieved (Noah, 20062007, 49). Tomich (1963) insisted that the education in Yugoslavia was much more than the mere acquisition of knowledge. It should become a national symbol to a people who, for many centuries, were subjected to foreign domination and prevented from acquiring a high degree of literacy (Filipović, 1974, 525-532).

Filipović furthermore explained that the reform continued and in 1970 the Resolution on the Development of Education on an Autonomous Basis was passed and further supported the ideals of life long learning, adult learning and self determination at the local level. From 1954 until Tito's death in 1980, education in Yugoslavia was guided by these ideals.

The Professor pours another cup of coffee into her cup and continues:

The university had a social responsibility for transferring knowledge and social understanding to the younger generations as described in the 1954 aims for education. As Tito understood it, it is through education that a sense of community is developed. That is what the university provided; a sense of belonging. We had nothing during the war, but we were students at the University of Sarajevo. We studied in Sarajevo. We were part of a community in Sarajevo and we had a sense of belonging and support. The University of Sarajevo stood because we were the students at the University of Sarajevo. The academicians taught because we all belonged to the University of Sarajevo. It was there for us, and we were there for it.

The strength of the commitment instilled in Yugoslavia citizens about the importance of education is remarkably demonstrated in the following account of the former student, now Professor, who lived through the siege of Sarajevo. 
If there was a massacre, it was an excellent excuse for coming late to the lecture, but these "freaks" were not turning a blind eye. These "weirdoes" (but perhaps we as active students in a war zone were as well) were our true standard of normality. To be normal-where everything is abnormal and turned on its head for such a long time, means to be normal. Being abnormal in a world where anything is abnormal, means trying to maintain a modicum of normality. And that norm is not determined by your profession, but by your life calling. Being a teacher and a student, but both at the same time (because the real teachers never give up their need for knowledge) meant to hope for life during the siege.

Not knowing when the next bomb or sniper shot would strike meant living was an attempt to take just a few more moments in this world to explore the important questions in life and to continue to ask questions. Being a student meant to fight for the indestructibility of knowledge, not only in material forms, but in that form of spiritual passion for discovery and learning. We needed to feel alive and this was reflected in the experience of survival through the adrenaline rush that the mere attending of the classes created. "Being" meant having the curiosity of a child for the world around us, no matter how bizarre or nonsensical that world appeared. We faced the dilemma of a new kind of normality in the state of siege. We had to find something to "be" and in this case the learning is "being."

This kind of escapism (which to outside eyes may have seemed odd) helped preserve normality. We lived for the moment! We did not need yoga, fitness classes, fancy gyms, meditation, or other New Age "Live in the moment" techniques. We were healthy in mind because we lived a surrealist vision of what was abnormalwhich become normal. We were looking death in the eye daily and simply made the existential choice worthy of Hamlet; we made the decision: "to be."

When we were assigned the well-known essay topic "From home to school" the daily journey became a question of "To be or not to be." To be late at the lecture meant an absence from class, but sometimes for some of us even an absence from life. Escapism through learning was a form of gratitude for surviving the moment.

Imagine yourself under these circumstances. If you were in high school during the siege, at 15 or 16 in 1992, today you would be 35 or 36 in 2012. If you live in Bosnia-Herzegovina as this part of the former Yugoslavia is now called, you most likely have started a family. You will be working, perhaps even finishing up an advanced degree. If you were a university student in 1992, your life as a student was so significantly 
tormented by the war but, as this narrative describes, education made surviving the war less complicated:

Classes took place and we tried to have fun as before. When there was no shooting we sat in the parks and playgrounds playing unplugged guitar and singing without electricity. All in all, our student days passed by in the illusion of normality. Everything was the same, except that everything was different. In fact, we were different, and everything was different, and so it seemed in a strange way that everything was the same. You would answer a question about polyvalent chemical compounds, but condensed air escaped from your mouth because the room was freezing and there was no heat.

A Professor normally listens to your answer and records a grade. But there were no grade books. Some were luckier than others and managed to retain their pre-war grade books or managed to acquire those unused books from before the war that still bore that country image of the ears of corn and the red five-pointed stars, the Yugoslavian coat of arms symbol.

Red colour took on a greater significance; it became a bleeding red symbol. Red colour was everywhere, both on our symbols and on our streets. But it was gone, either because there were not books and texts with our symbols or it was the blood of our neighbours. And eventually the blood and the red were gone, because either the rain washed it from the streets or by the solidarity of the citizens. There were so many killed, and each death was known. There was the place where the guy from the fifth floor lost his head; this was where those girls were massacred. We began to feel that a demon hovered in those places and they were avoided. But they soon became something like a sacred place and the more time passed, more of these holy places appeared. Each piece of sidewalk became a sacred place and in the Holy Sarajevo, everything became holy. Everything can have dual symbolism.

The s iege began on April 6, 1992 and ended on February 29, 1996 and during that horrific time a level of education continued in spite of the destruction of almost every building and the daily death of faculty, staff and students. The Professor relates an experience not long ago illustrating the abstract, often surreal differences in conscious acceptance:

Recently, I visited the U.S. to give a lecture about Bosnian film. On the second day of lectures the snow began to fall and all the classes were cancelled. There was not much snow on the streets 
but the University was concerned about the condition of the roads and especially on the campus where a traffic accident could happen. Because of these unsuitable conditions, a potential victim might sue the university. This incident reminded me of our University and the dissimilarity of the dramatic situation. We were forced to cancel classes due to heavy showers of shells but in the States it was simply freezing rain. Of course we had no one to sue and no one to hold accountable.

Why did education continue when there was so much to lose by venturing out on the streets within site of the snipers? The answers to that question are the key to understanding the commitment to education that was instilled in the former Yugoslavia.

Russo (2000) states that throughout the war years schools in Sarajevo, home to about 400,000 people at that time, remained open. More than 1600 children and 15,000 adults were killed. But given the key role that education played in unifying the former Yugoslavia it did not happen by accident that schools, pre-school institutions and faculties were the target of the aggression. It also speaks to the commitment to education of the people under the siege:

I was a student during the war, and now I am a lecturer. Perhaps there was no State as we knew and fought for, but there was the University of Sarajevo. When so much and so many did not survive, when there was no electricity, water or food, and when death was taking its toll, the university continued. My only real sense of belonging, which can be compared with a sense of belonging to a system, is my feeling that I have for the University of Sarajevo, based on memories of studying during the Siege.

The University of Sarajevo stood against the insanity of the war, but ironically it was also clear that three professors were among the group that planned and launched the war. The key figures of the Serbian Democratic Party (SDS) were Biljana Plavšić, professor of Biology; Nikola Koljević, professor of English and most infamously, Radovan Karadžić, psychiatrist, Clinic Center of the University in Sarajevo.

Fear of contact with those who are different creates a nationalistic and religious beast of a man, and erases all the knowledge 
and breadth of education. This was what gave the justification for the destruction and madness, devastation and bloodshed. These people and of course many others were madly frightened of others, and they did everything to attack other people so their fear could be justified.

The system of general education in the former Yugoslavia had more strengths than weaknesses in comparison to other education system throughout the world. The only drawback of the old system of education was that students were not given enough experience to understand the benefits of self-esteem and the consequences of propaganda. Tito's legacy did not last long enough to implement the aims of education to help the nation to stand against such propaganda. In Yugoslavia the education system was lacking only one thing-instilling confidence and self-consciousness in students.

Their fear of the teacher, developed in the early years of the development of a child's personality, prevented students from developing critical thinking. This allowed the conceptual designers of the siege of Sarajevo to manipulate the insecurity of the people. The tribal awareness of the people educated prior to the Tito's reforms was simply connected to the archetypes of Good and Evil. The people were subconsciously divided between an "us and them." The result is homogenization with strong nationalist tendencies and stereotyped propaganda about the evils of others (them). This creates an urge to defend us, even if the actual threat is only a manipulated illusion. The need for defence becomes an attack, so it creates war and genocide. Tito's great concern that a nationalistic fever could destroy Yugoslavia unfortunately came true.

The resistance of the students and professors against the madness
that descended from the hills, where the death and mutilation of
Sarajevo began, was a copy of Dali's Dreams. Surrealism was
created as a response to the meaninglessness and absurdity of
war, bloodshed and destruction. That was the cry of the
subconscious and repressed in dreams for preserving the normality.
The reality of our actual possession and manipulated obsession
in our "possessors'" subconscious is normality of abnormal
in surrealism, which were guarded by professors and students at
the University of Sarajevo. That is what allowed us to survive
the madness of war. We looked at Dali's reality in the eyes 
and saw the meaning and meaninglessness of life and death. If we avoided shelling that day, we pretended to continue living as we did in our previous lives. We played a game with our professors. We pretended that everything was as it had been before. They, in turn, also lived their pre-war lives and enjoyed the authority they previously had.

If the work you typed all night by candlelight on an old borrowed typewriter was not good, it could be used as a fire starter in stoves that were heating classrooms in which the sheet of UNPROFOR (United Nations Protecting Forces) nylon waved instead of glass in the windows.

This experience should be a constant reminder to the coming generations. Such a formula can be recognized in the language of hatred, in manipulating the archetypes of Good and Evil, and propaganda stereotypes that arouse our tribal consciousness and hatred. The next generations need to recognize and destroy this virus of racism and violence. The fear of the different we can overcome by learning about others and therefore there is no greater joy than winning the battle over pernicious propaganda and ignorance.

From these reminiscences there is still a lot more to learn. Misfortune, pain and trauma can be the greatest teacher. The normal psyche in each of us tends to forget things, deny and repress reality. Because we have survived the trauma, we think it cannot come back. But it can, just as it is happening today in Libya, Afghanistan, Iraq, Palestine, Bahrain, Egypt, Yemen, Japan and elsewhere. The University of Sarajevo survived the Siege, thanks to students and teachers for whom learning gave hope and endurance. Knowledge enables us, if properly assimilated, to be free. Let us hope that no one ever has to endure and experience such a surrealistic nightmare that occurred in Sarajevo.

The treatise, 1479 Days, the Siege of University of Sarajevo, states:

Despite the unbearable difficulties of living in the city under the siege, exams were (being) passed, $\mathrm{MA} / \mathrm{MSc}$, and $\mathrm{PhD}$ degrees awarded and the most important academic debates were conducted. That grit and resistance in the greatest difficulties and troubles is proof of an unbreakable spirit of this city and this people of power, strength and will to survive the cataclysm with heads up. University teachers living in Sarajevo showed the whole world that the dignity of the academic community can be defended even under horrifying conditions, and they showed it by doing their job with love, teaching students about the values of humanity and inheritances of civilization, about antifascism and humanism about patriotism and solidarity. ... Aware of tragedy, filled with bitterness, pain and contempt for the monsters that conducted the siege of the city and committing countless crimes 
against its citizens, we give you this testimony. Hordes, guided by criminal hatred, attempt to wipe out one spirit, one people, one city, one University, through genocide and barbarity. By this overview we want to show them they did not succeed in their attempts. Our testimony must not stay untold and it deserves a place in world history annals, as a message, a lesson and a reminder (Čaklovica, 2010).

An important conclusion can be made about the ongoing concern about the loss of pride and patriotism that the citizens of the Former Yugoslavia felt toward their education. Today it is not uncommon to hear young and old alike state that education before the war was far better than post-war education. Since the signing of The General Framework for Peace in Bosnia-Herzegovina (also known as the Dayton Accords) which was completed in November 1995 and signed in Paris on December $14^{\text {th }}, 1995$, territory divisions were created and in many instances allowed the divisions of ethnic minorities and practices to be supported. Several other key factors seem to be at work, as well. First, the education system is no longer centralized, relying instead on a highly regional network of canton education ministries who do not work together on issues such as curriculum and nationalistic concerns. Secondly and more problematic is the recent addition of religious education in the public schools. This is a very significant change from the Yugoslavia era where church and state were strictly separated. Children and their families may choose to participate, however the choice non-participation can be quite difficult for a child who practices a religion that is not taught at their particular school. It is not uncommon for schools to offer 2 separate curriculums in the same building, hence the expression "two schools under one roof."

A third major change is that after the war textbooks began to cover material that is ethnically slanted. Local history for one particular ethnic group might well suggest that other groups are inferior in some way. The sense is the creation of the "us and them" dichotomy described previously. From the previous socialist perspective, the education system supported the ideology of brotherhood, patriotism, and selfdetermination for the improvement of the society. Today these three new "innovations" can be seen as taking the country backwards and 
perhaps re-establishing the ideals that led to the war and the siege. The hope for the return to a former state of excellent education lies with the many educators who express concern about the segregation and religiosity currently in place. Together with the families in the communities, a choice for who governs makes a difference. Given the status quo, the system encourages children to disrespect each other. That certainly was neither Tito's expectation nor dream nor that of his ministers. His legacy was to be a united Yugoslavia with a highly educated population who could complete successfully on a global stage.

The afternoon sun sets on Sarajevo Professor gets out of her chair to remove the cold cups of coffee and plates on the table. She stops abruptly and for a second of silence, and then begins to speak:

We were sold a story about a system that we have adopted as a fictional hot water. According to this logic "if it were good it would last!" I think this logic is flawed because even though we say that "there is no state," we can say with certainty that "there is a university". Under shelling or under external reforms, the university survives and will survive because of curious people seeking knowledge.

Today we say that, "There is No state." Obviously there is a "state" since there are laws with police, traffic is carried out properly, and we have electricity, water, food and heating. On Google's map we look fine and you can see our natural beauty, a potential pyramid and the opportunity to build better highways. Historical and cultural monuments are attracting people with backpacks and cameras from all over the world. We even have music for our new anthem even though it does not have words. But when we say that our country does not exist, it is because Yugoslavia no longer exists. The feeling of belonging and the patriotism that was fuelled with such enthusiasm during socialism is gone. We had a deep sense of belonging, a sense of security and patriotism. Human beings are social and school provided that during the war. When we say that there is no state, we are thinking about the present and future, of generations to come and in what ways will they degenerate without the support of a sense of belonging and support by civil society mechanisms. There is much that could change to take us back to the aims of the former state that instilled our sense of pride and effort in education. 
The war was unnecessary; however, there are always reasons for war. Once asked about his miracles, and what he abhors the most, Jesus (or Isaa) said the following: "The Lord gave me the power to bring back the dead, to bring back eyesight to the blind and hearing to deaf, but the power to cure a fool he did not give me" (Karahodžić, Isa $u$ knjigama sufija, 119). Ignorance is curable, but human stupidity is not. By being in its sights, we become the victims of the propaganda of those acting to achieve power and profit. Such fools are willing to start wars between brothers and neighbours, who are ready to kill children and women, to place a sniper to shoot at civilians and stray dogs on the streets in order to fulfil their goals. What was accomplished by the siege was clearly a strengthening of the commitment to education through the University of Sarajevo, but so much has been lost. 


\section{References}

Beekman, Linda Flynn. 2004. War cake: a witness in the siege of Sarajevo. Clearwater, Fla.: L.F. Beekman.

Crvenkovski, Krste. 1961. "Ability and Educational Opportunity in Present Day Yugoslavia." International Review of Education 7, no. 4: 1921-2001.

Čaklovica, Faruk. 2010. 1479 days, the siege of University of Sarajevo: a documentary overview of events 1992-1995. 2nd ed. Sarajevo: University of Sarajevo.

Filipović, Dragomir. 1974. "Lifelong Learning in Yugoslavia." International Review of Education 4, no 20: 525-532.

Karahodžić, Mehmed. 2002. Isa u knjigama sufija. Sarajevo: Mehmed Karahodžić.

Kreso, Adila. 2008. "The War and Post War Impact on the Educational System of Bosnia and Herzegovina." International Review of Education No 3/4, 54: 353-374.

Russo, Charles. 2000. "Religion and Education in Bosnia: Integration not Segregation." European Journal for Education Law and Policy 4, no. 2: 121-129.

Sobe, Noah. 2006-2007. "U.S Comparative Education Research on Yugoslavia Education in the 1950s and 1960s." European Education 4, no. 38: 44-64.

Šoljan, Nikša. 1978. "The Reform of the System of Pre-service and Inservice Teacher Training in Yugoslavia: Towards the Educating Community." International Review of Education 1, no. 24: 75-80.

Tomich, V. 1963. "Education in Yugoslavia and the new reform: the legal basis, organization, administration and program of the secondary schools." US Department of Health, Education and Welfare (20).

Živojnović, Petar. 1959. "School Reform in Yugoslavia." International Review of Education 4, no. 5:469-477 